\title{
Performance evaluation of cassava starch-zinc nanocomposite film for tomatoes packaging
}

\author{
Adeshina Fadeyibi, ${ }^{1}$ Zinash D. Osunde, ${ }^{2}$ Evans C. Egwim, ${ }^{3}$ Peter A. Idah ${ }^{2}$ \\ ${ }^{1}$ Department of Agricultural and Biological Engineering, Kwara State University, Malete; ${ }^{2}$ Department of Agricultural \\ and Bioresources Engineering, Federal University of Technology Minna; ${ }^{3}$ Department of Biochemistry, Federal \\ University of Technology Minna, Nigeria
}

\begin{abstract}
Biodegradable nanocomposite films are novel materials for food packaging because of their potential to extend the shelf life of food. In this research, the performance of cassava starch-zincnanocomposite film was evaluated for tomatoes packaging. The films were developed by casting the solutions of $24 \mathrm{~g}$ cassava starch, $0-2 \%(\mathrm{w} / \mathrm{w})$ zinc nanoparticles and $55 \%(\mathrm{w} / \mathrm{w})$ glycerol in plastic mould of $12 \mathrm{~mm}$ depth. The permeability of the films, due to water and oxygen, was investigated at $27^{\circ} \mathrm{C}$ and $65 \%$ relative humidity while the mechanical properties were determined by nanoindentation technique. The average thickness of the dried nanocomposite films was found to be $17 \pm 0.13 \mu \mathrm{m}$. The performances of films for tomatoes packaging was evaluated in comparison with low density polyethylene (LDPE; $10 \mu \mathrm{m}$ ) at the temperature and period ranges of $10-27^{\circ} \mathrm{C}$ and $0-9$ days, respectively. The quality and microbial attributes of the packaged tomatoes, including ascorbic acid, $\beta$-carotene and total coliform were analysed at an interval of 3 days. The results revealed that the water vapour permeability increased while the oxygen permeability decreased with the nanoparticles $(\mathrm{P}<0.05)$. The hardness, creep, elastic and plastic works, which determined the plasticity index of the film, decreased generally with the nanoparticles. The films containing 1
\end{abstract}

Correspondence: Adeshina Fadeyibi, Department of Agricultural and Biological Engineering, Kwara State University, Malete, Nigeria.

Tel.: +234.0.7034867681. E-mail: adeshinaf601@gmail.com

Key words: Nanocomposite; microbial load; packaging; shelf life; tomatoes; $\beta$-carotene.

Acknowledgements: the authors would like to thank the Tertiary Education Trust Fund (TETFund) of the Federal Ministry of Education, Nigeria and the management of the Federal University of Technology, Minna, Nigeria for providing the grant and work space for carrying out this research.

Received for publication: 5 May 2016.

Accepted for publication: 3 November 2016.

(C) Copyright A. Fadeyibi et al., 2017

Licensee PAGEPress, Italy

Journal of Agricultural Engineering 2017; XLVIII:565

doi:10.4081/jae.2017.565

This article is distributed under the terms of the Creative Commons Attribution Noncommercial License (by-nc 4.0) which permits any noncommercial use, distribution, and reproduction in any medium, provided the original author(s) and source are credited. and $2 \%$ of the nanoparticles suppressed the growth of microorganisms and retained the quality of tomatoes than the LDPE at $27^{\circ} \mathrm{C}$ and day- 9 of packaging $(\mathrm{P}<0.05)$. The results implied that the film could effectively be used for tomatoes packaging due to their lower oxygen permeability, hardness, elastic and plastic works.

\section{Introduction}

Packaging can be regarded as an industrial and marketing technique for keeping food in its ideal condition over an appreciable period before consumption (Chinma et al., 2015; Fadeyibi et al., 2016a). It is also a means of encouraging the purchase of food, especially as the information about the product can be printed on the package for consumers to see (Guilbert et al., 1996). Also, packaging enables the distribution of food and food products to places where they are not grown, thus ensuring the availability of the food in places where the commodity is scarce (HernandezIzquierdo and Krochta, 2008). In Nigeria for instance, foods are usually wrapped in nylons, old newspapers, animal skins and leaves. This practice often encourages quality decline of the packaged products because the materials provided little or no protection against air, light, moisture and bacteria (Ortega-Rivas, 2003).

There are basically three different categories of materials identified for use in the packaging of fruits and vegetables; and they are: traditional, synthetic and nano-reinforced materials (Janhasgir and Leber, 2007; Chaudhry et al., 2008). The traditional packaging materials are usually made from leaves, vegetable fibres, wood, papers and earthenware (Ortega-Rivas, 2003). The synthetic and nano-reinforced packaging materials, on the other hand, belong to the same class of conventional materials, where plastics and thermoplastics are often used (Henriette et al., 2009). The synthetic packaging materials are made from petroleum based monomers, and constitute serious environmental concern because they are practically non degradable. The polyvinylchloride, low-density polyethylene (LDPE) and high-density polyethylene (HDPE) materials are common examples of synthetic packages often used in the food industries. The use of these materials has often been restricted because of the environmental problem they can cause. The addition of organic or inorganic particles in the range of 1-100 nm to starch or protein-based thermoplastics provides a modern and excellent packaging technology, which is called nano-reinforced packaging material (Zhang et al., 2008; Emamifar et al., 2011; de Moraes et al., 2012). This class of packaging material is desirable because it is biodegradable, flexible, lightweight and comparable to the LDPE materials in terms of resistance to tearing (Castelló et al., 2010; de Moraes et al., 2012). Also, the packaging material has been reported to protect the food against moisture, oxygen, odours or microorganisms because of the antimicrobial (Nascimento et al., 2012; 
Tankhiwale and Bajpai, 2012) and oxygen scavenging activities (Avella et al., 2005; Fadeyibi et al., 2016b) of the nanoparticles embedded in the polymer. However, the use synthetic polymers like the LDPE and HDPE has so far being discouraged probably due to the high amount of heat, which is capable of encouraging microbial deterioration, associated with such packages (Auras et al., 2005). Nowadays nano-reinforced materials, such as the nanocomposite films, have replaced the synthetic materials in food packaging application. But, the production of most of the nanoparticles used is quite expensive and sometimes toxic, thus limiting their application. Hence, there is the need for an alternative composite material reinforced with a readily available and less toxic material, like zinc, for food packaging application. Research results of Luo et al. (2013), Fadeyibi et al. (2016a), Jin et al. (2009), Tankhiwale and Bajpai (2012) and Nafchi et al. (2013) have already given credence to the potential application of zinc oxide nanoparticles in food packaging. In fact, the deliberate inclusion of zinc nanoparticles in food packaging material, at a controlled amount, might not likely render the packaged food toxic or unfit for human consumption (Jin et al., 2009; Tankhiwale and Bajpai, 2012). This is because the zinc particles have their particles size in the range of 4-9 $\mathrm{nm}$ (Fadeyibi et al., $2016 \mathrm{~b}$ ) and only $2 \%$ has often been used as fillers (Teodoro et al., 2015) in the packaging materials. Also, the European Food Safety Authority (EFSA, 2016) recommended a maximum of $2 \%$ zinc concentration for food application, and this was not exceeded in the present investigation. Some major breakthroughs has been recorded in this area of research, like in the application of edible films in packaging and coating of fresh fruits and vegetables (Chinma et al., 2015), and especially in using nanoparticles like montmorilonite and acetylated starch (Emamifar et al., 2011; Teodoro et al., 2015). However, the application of cassava starch-zinc nanocomposite film in the packaging of tomatoes has not been reported. Also, there are still more to know especially the roles of the zinc nanoparticles in ensuring quality retention and microbial growth inhibition of the produce. Therefore, the objective of this research was to evaluate the performance of cassava starch-zinc nanocomposite film for microbial growth inhibition and retention of quality, including the $\beta$ carotene, ascorbic acid and moisture contents of tomatoes.

\section{Materials and methods}

\section{Materials}

A basket ( $2 \mathrm{~kg}$ ) of day old, firm ripe, oblong shaped, roma variety tomatoes were bought from the commercial market at Kateregi, Niger State and transported to the Crop Processing and Storage Laboratory of the Federal University of Technology, Minna. Ten pieces of the tomatoes, with average length $(30.56 \mathrm{~mm})$, diameter $(11.35 \mathrm{~mm})$, weight $(100 \mathrm{~g})$ and without bruises were carefully selected from the basket and immediately used for the packaging experiment. The cassava starch and zinc nanoparticles used were prepared according to the methods reported by Fadeyibi et al. (2014) and Fadeyibi et al. (2016b), respectively. The glycerol (analytical grade) used was obtained from the Science, Equipment and Development Institute (SEDI), Niger State, Nigeria.

The nanocomposite films used for the tomatoes packaging were prepared from the blends of $55 \%$ glycerol and $0 \%$ zinc nanoparticles (55-0-17), 55\% glycerol and 1\% zinc nanoparticles (55-1-17) and 55\% glycerol and 0\% zinc nanoparticles (55-2-17), together with LDPE $(10 \mu \mathrm{m})$ material.

\section{Preparation of film and size determination}

The cassava starch zinc-nanocomposite film was prepared by dispersing the nanocomposites, consisting of blends of $0-2 \%$ zinc nanoparticles, $55 \%(\mathrm{w} / \mathrm{w})$ glycerol and $24 \mathrm{~g}$ of cassava starch, into $600 \mathrm{~mL}$ distilled water. The resulting solutions were heated for 30 min to form viscous thermoplastic liquids and thereafter transformed into films by casting in a plastic mould. The size of the mould was determined by measuring the surface area of $100 \mathrm{~g}$ of tomatoes. This was achieved by wrapping the fruits with aluminium foil and tracing the layout on the graph paper. The total surface area of the mould, measuring $350 \times 180 \mathrm{~mm}$, was evaluated from the expression in Eq. (1) (Fadeyibi et al., 2016b). The depth of the mould, which took care of shrinkage, determines the thickness of the dried films (Kampeerapappum et al., 2004). The plastic micrometre was used to establish the average thickness of the dried samples of the film as $17.38 \pm 0.13 \mu \mathrm{m}$.

$T S A=N a+e$

where: $N=$ number of biomaterial required to be rapped, $a=$ surface area of tomatoes $\left(3467 \mathrm{~mm}^{2}\right.$ ), $e=$ allowance (assumed 600 $\left.\mathrm{mm}^{2}\right)$ and TSA $=$ total surface area of the mould $\left(\mathrm{mm}^{2}\right)$.

\section{Characterisation of cassava starch-zinc nanocomposite films}

\section{Water vapour permeability}

The water vapour permeability (WVP) of the nanocomposite films was determined according to Aydinli and Tutas (2000). The film sample was cut into circle of $4 \mathrm{~cm}$ diameter and placed on petri dish filled with $50 \mathrm{~mL}$ deionised water to expose it to $100 \%$ relative humidity. By adding a solution of common salt (sodium chloride) at ambient temperature, the setup was subjected to a temperature and relative humidity of $25^{\circ} \mathrm{C}$ and $65 \%$, respectively. The petri dish was allowed to equilibrate for two hours before taking the initial weight. The final weight was taken at the end of $1 \mathrm{~h}$. Water vapour transmission rate and permeability were determined empirically as expressed in Eqs. (2) and (3). The experiment was repeated three times for each sample of the films and the average values computed were the water vapour permeability of the films.

$$
\begin{aligned}
& \text { WVTR }=G / t A \\
& W V P=(W V T R / \Delta p) \times L
\end{aligned}
$$

where: $W V T R=$ water vapour transmission rate $\left(\mathrm{g} / \mathrm{s} . \mathrm{m}^{2}\right), W V P=$ water vapour permeability (g/m.Pa.s), $G$ is the change in mass $(\mathrm{g})$, $t$ is the time (h), and $A$ is the area of the mouth of the petri dish $\left(\mathrm{m}^{2}\right), L$ is the thickness of the test specimen $(\mathrm{mm})$ and $\Delta p$ is the partial pressure difference of water vapour across the film.

\section{Oxygen permeability}

The oxygen permeability (OP) of the cassava starch-zinc nanocomposite film was determined empirically using the column absorption method (Fadeyibi et al., 2016b). This was achieved by cutting $1.23 \mathrm{~cm}^{2}$ of sample of the film in the absorption column, immersed in a water batch, equipment with a hose from the cylinder containing oxygen gas. The sample was exposed to the oxygen gas, by this arrangement, for a period of one hour at $63 \%$ relative humidity (RH) and $25^{\circ} \mathrm{C}$. The oxygen concentration (\%) in the column was subsequently measured, using an electronic balance 
( $0.0001 \mathrm{~g}$ sensitivity) at the end of one hour. The data of properties shown in Table 1 contains the values of some parameters, including an established correlation for the computation of $P_{H 2} O^{\text {sat }}$, used for the calculation of the oxygen permeability.

The difference in the partial pressure $(\triangle P)$ was computed using Eqs. (4) to (7).

$$
\begin{aligned}
& {\left[\mathrm{O}_{2}\right]=m_{2} / 1000 \mathrm{M}} \\
& {\left[\mathrm{O}_{2}\right]_{i}=\left(\mathrm{RH} \times \mathrm{PH}_{\mathrm{H} 2} \mathrm{O}^{\mathrm{sat}}\right) / 100 \mathrm{RT}} \\
& {\left[\mathrm{O}_{2}\right]_{t}=\left(\left[\mathrm{O}_{2}\right] /\left[\mathrm{O}_{2}\right]_{i}\right) \times 100 \%}
\end{aligned}
$$

Therefore, $\triangle \mathrm{P}_{\mathrm{O} 2}=\left(\left[\mathrm{O}_{2}\right]_{t}-\left[\mathrm{O}_{2}\right]_{i}\right) \times P_{\text {total }}$

where: $\left[\mathrm{O}_{2}\right]_{t}$ is the oxygen concentration inside the absorption column at time $t,\left[\mathrm{O}_{2}\right]_{i}$ is the initial column oxygen content, $\mathrm{mO}_{\mathrm{O}}$ is the mass of oxygen gas absorbed by the cassava starch nanocomposite film in the column, $M$ is the molar mass of oxygen gas $(16 \mathrm{~g} / \mathrm{mol})$, $R$ is the molar gas constant $\left(8.31 \times 10^{7} \mathrm{~m}^{3} \mathrm{~Pa}^{\mathrm{m}} \mathrm{mol}^{-1} \cdot \mathrm{K}^{-1}\right)$.

The total pressure $\left(P_{\text {total }}\right)$ was calculated by taking into account the influence of the temperature $(T)$ on the saturation pressure of water vapour $\left(\mathrm{PH}_{2} \mathrm{O}^{\text {sat }}\right)$ and $\mathrm{RH}$ as shown in Eq. (8). The value of $O P$ was subsequently computed from Eq. (9).

$P_{\text {total }}=P_{\text {atm }}-P_{H 2 O^{\text {sat }}}$.RH

$\mathrm{OP}=\Delta m \Delta x / \Delta t A \Delta P O_{2}$

The procedure was repeated three times and the oxygen permeability was taken as the average of the oxygen permeability measured under the steady state condition.

\section{Mechanical properties}

The nanoindenter was used to determine the mechanical properties of the nanocomposite films. A typical profile of the load-displacement curve of the film, obtained from the nanoindenter, is shown in Figure 1A.

The profile was used to compute the hardness (Syed et al., 2013), Young's modulus (Tall et al., 2007), elastic recovery (Tall et al., 2007) and creep (Jian et al., 2013) from the empirical relationships in Eqs. (10) to (13). The strain was computed as the ratio of the recovered depth to the original depth or thickness of the nanocomposite film. The stress was computed as the product of the strain and the Young's modulus of the material. The elastic and plastic works correspond to the areas under the loading and the unloading parts of the hysteresis loop.

$H=P_{\max } / A_{c} h_{c}$

where $P_{\max }=$ maximum load, $A_{c}=$ contact area $\left(\mathrm{nm}^{2}\right), h_{c}=$ contact depth (nm), $H=$ hardness of the nanocomposite film.

$1 / E r=\left[\left(1-v^{2}\right) / E\right]+\left[\left(1-v_{i}^{2}\right) / E_{i}\right]$

where: $E r=$ reduced modulus $(\mathrm{MPa}), v=$ poison's ratio of the nanocomposite film, which was obtained by assuming that the material is isotropic in nature with the elastic modulus evenly distributed in all crystallographic directions $=0.5, v_{i}=$ poison's ratio of the diamond indenter $=0.25, E_{i}=$ elastic modulus of the diamond indenter $=1140 \mathrm{GPa}, E=$ elastic modulus of the nanocomposite film.
$E R P=h_{e} / h_{f}$

where $h_{e}=$ recovered depth $(\mathrm{nm}), h_{f}=$ depth of the unloading curve of the profile $(\mathrm{nm}), E R P=$ elastic recovery parameter.

$\in=1 / h_{c} \quad \mathrm{~d} h_{c} / \mathrm{dt}$

where: $h_{c}=$ depth at the holding region of the profile $(\mathrm{nm}), t=$ holding time $(0.5<\mathrm{t}<1), \in=$ strain rate or creep $(\mathrm{nm} / \mathrm{s})$.

\section{Tomatoes packaging and quality investigation}

Packaging was carried out at temperature and period ranges of $10-27^{\circ} \mathrm{C}$ and $0-9$ days, respectively. The samples of tomatoes were assembled in crates, wrapped using the nanocomposite materials and stored in the incubator to achieve the desired temperature. The total coliform and quality parameters of the fresh tomatoes were evaluated at day 0 , and then re-evaluated at an interval of 3 days for a total storage period of 9 days.

The microbial loads of the packaged tomatoes were determined by Pour Plate method. Nutrient Agar was used to culture the bacteria growth in the media. $1 \mathrm{~mL}$ of the diluents was poured into sterile Petri dishes and about $10 \mathrm{~mL}$ of nutrient agar was carefully added to it. The plate was stirred gradually to solidify and thereafter inverted and incubated at $37^{\circ} \mathrm{C}$ for $24 \mathrm{~h}$. The sabreaud dextrose Agar was used to culture the growth of fungi in the media. An antibiotic (chloramphenicol) was added to the cultured plate, to ensure that only fungi were the dominant microorganisms in the colony, inverted and incubated for $48 \mathrm{~h}$. The microbial growths were determined using the serial dilution (Guilbert et al., 1996). Also, the methods of quality analyses, as described by Onwuka (2005) were used for the analyses of the total soluble solids, moisture content, vitamin $C, \beta$-carotene and titratable acidity of the packaged tomatoes samples.

\section{Statistical analysis}

The data obtained were analysed using fully nested hierarchical analysis of variance (ANOVA) in a $4 \times 4 \times 3$ factorial experiment, corresponding to the levels for each of the randomly assigned source of variation (packaging material, storage period and temperature). Evidence was sought for their individual influence on each of the responses (total soluble solids, moisture content, $\beta$ carotene, titratable acidity and total coliform) of the packaged tomatoes at $\mathrm{P}<0.05$ significant level. The extents of variation in the response due to the influencing sources were also investigated.

Table 1. Data of properties used for the computation of oxygen permeability.

\begin{tabular}{lc} 
Parameter & Value \\
Volume of the column $\left(\mathrm{V}_{\mathrm{v}}\right)$ & $17.42 \times 10^{-3} \mathrm{~cm}^{3}$ \\
Density of oxygen $\left(\rho_{02}\right)$ & $0.00133 \mathrm{~g} / \mathrm{m}^{3}$ \\
\hline Atmospheric pressure $\left(\mathrm{P}_{\mathrm{atm}}\right)$ & $101325 \mathrm{~Pa}$ \\
Saturated pressure of water vapour $\left(P_{\left.\mathrm{H} 20^{\mathrm{sat}}\right)}\right.$ & $\mathrm{P}_{22} 0^{\mathrm{sat}}=190.2 \mathrm{~T}$ \\
& $\left({ }^{\circ} \mathrm{C}\right)-1536.7(\mathrm{~Pa})$ \\
\hline Film area $(\mathrm{A})$ & $1.23 \times 10^{-4} \mathrm{~m}^{2}$ \\
\hline
\end{tabular}




\section{Results and discussion}

\section{Barrier and mechanical attributes of the films}

The effect of zinc nanoparticles on the permeability due to oxygen and water vapour of the cassava starch-zinc nanocomposite films were shown in Figure 1B. It can be seen that the water vapour permeability increased while the oxygen permeability decreased significantly with the nanoparticles $(\mathrm{P}<0.05)$ (Table 2$)$. Also conspicuous is the fact that the permeability was lower for the film without zinc nanoparticles than the ones with 1 and $2 \%$ of the fillers $(\mathrm{P}<0.05)$. It is likely that the presence of the nanoparticles altered the molecular arrangement of the lattice structure of the films with the resultant restriction of gas mobility and promotion of dipole-dipole interaction among the starch molecules, glycerol and the fillers. This can be corroborated by the findings of Avella et al. (2005) who reported that the water vapour permeability increased and the oxygen permeability decreased with the addition of small amount of clay particles into starch film. In similar researches undertook by Aydinli and Tutas (2000), Auras et al. (2003) and Dai et al. (2015), the permeability of edible films have been reported to be enhanced by the addition of different kinds and concentrations of the nanoparticles. Moreso, Zhang et al. (2008) and Amidi-Fazli and Amidi-Fazli (2015) reported that lower gas permeability of nanocomposite film is an advantage in food packaging and processing. Therefore, it can be viewed that the ability of the nanocomposite films to curtail oxygen transfer and promote moisture migration between the food and the package might be criteria for effective food packaging.

The influence of zinc nanoparticles on some of the mechanical properties of the nanocomposite films is shown in Table 3. It can be seen that the creep, which is essential in determining the strain rate sensitivity of the nanocomposite material, decreased with the nanoparticles. The hardness of the material decreased while the Young's modulus and elastic recovery parameter increased with the nanoparticles. Also, the elastic and plastic works, which determine the plasticity index of the materials, together with the strain and stress generally decreased with the nanoparticles. It is possible that at higher concentration of the nanoparticles, the plasticity index, which determines the viscoelastic behaviour of the resulting nanocomposite material, is promoted by the displacement of the lattice arrangement of the film. This can cause the material to be slightly ductile and stretchable to accommodate the tomato fruits during packaging. This agrees with the findings of Jorge et al. (2014) who reported that the presence of montmorilonite increased the mechanical properties of the film in their work on the mechanical properties of gelatine film blended with montmorilonite nanoparticles. In another related investigation, de Moraes et al. (2012) demonstrated that the inclusion of bentonite and cellulose fibre nanoparticles has the ability of improving the mechanical properties of starch composite films.

\section{Effects of temperature and period on the quality attrib- utes of packaged tomatoes}

The effects of storage period and packaging materials on TSS and TTA of tomatoes at 10,15 and $27^{\circ} \mathrm{C}$ are shown in Figures 2 and 3 . The TSS increased significantly $(\mathrm{P}<0.05)$ with storage period for the tomatoes packaged in the nanocomposite films and significantly decreased $(\mathrm{P}<0.05)$ with storage period for that in LDPE material, as shown in Figure 2. It can be seen that the tomatoes packaged in the film blended with $2 \%$ nanoparticles retained TSS than those packaged in the film blended with $1 \%$ and $0 \%$ nanoparticles. The contribution of the zinc nanoparticles to retaining the TSS was significant compared to their individual effect, which was not significant $(\mathrm{P}<0.05)$ (Table 4). Also, the variance component of the TSS indicated the contributions of temperature, storage period and packaging materials as $0 \%, 27.5 \%$ and $72.5 \%$ of the total variability, respectively. Thus, this may mean that the temperature and period variations did not significantly influenced the TSS as does the packaging materials. The increase in the TSS of packaged tomatoes may be associated with the increase in the concentration of the dry matter at higher packaging period and temperature. Similarly, the TTA, which indicates the total acidity of the tomatoes, increased significantly $(\mathrm{P}<0.05)$ with storage period at 10,15 and $27^{\circ} \mathrm{C}$, as shown in Figure 3 . The variance component of TTA was estimated as $65.1 \%, 4.9 \%$ and $30.1 \%$ of the total variability for temperature, storage period and packaging materials, respectively (Table 4). This implies that the significant increase in the titratable acidity with the storage period may be majorly due to temperature variation. The amount of TTA in the tomatoes packaged in the LDPE was considerably higher than the ones packaged in the nanocomposite films at all the temperatures considered. The

Table 2. Regression analysis between zinc nanoparticles and permeability of the films.

\begin{tabular}{lcccccc} 
Parameter & Predictor & Coef. & SE Coef. & t & \multicolumn{2}{c}{ P sq. (\%) } \\
WVP & Constant & 2.56 & 0.291 & 8.81 & 0.072 & 81.3 \\
& Zinc nanoparticles & 0.47 & 0.225 & 7.09 & $0.024^{*}$ & - \\
OP & Constant & 0.782 & 0.086 & 9.12 & 0.070 & 84.5 \\
& Zinc nanoparticles & -0.155 & 0.066 & -8.33 & $0.038^{*}$ & - \\
\hline
\end{tabular}

Coef., coefficient; SE, standard error; sq., square; WVP, water vapour permeability; OP, oxygen permeability. *Significant at $\mathrm{P}<0.05$.

Table 3. Influence of zinc nanoparticles on some mechanical properties of cassava starch-zinc nanocomposite film.

\begin{tabular}{lcccccccc} 
No. of trial & Zinc NP $(\%)$ & $E(\mathrm{~nm} / \mathrm{s})$ & ERP & EW $(\mathrm{pNm})$ & $\mathrm{H}(\mathrm{NPa})$ & $\mathrm{PW}(\mathrm{pNm})$ & $\delta(\mathrm{pNm})$ & $\tau\left(\mathrm{N} / \mathrm{Nm} \mathbf{m}^{2}\right)$ \\
1 & 0 & 9.766 & 0.4128 & 14.05 & 4.980 & 16.224 & 0.00312 & 0.10574 \\
2 & 1 & 11.832 & 0.0000 & 28.80 & 7.060 & 16.4395 & 0.04706 & 0.45671 \\
\hline 3 & 2 & 8.932 & 0.4123 & 10.66 & 9.070 & 10.248 & 0.01065 & 0.67337 \\
\hline
\end{tabular}

NP, nanoparticles; $\in$, creep; ERP, elastic recovery parameter; EW, elastic work; H, hardness; PW, plastic work; $\delta$, strain; $\tau$, stress. 
nanoparticles present in the new packaging materials might influence the likely formation of basic hydroxide, which is capable of decreasing the TTA of the tomatoes at higher storage temperature and period.

The moisture content, ascorbic acid and $\beta$-carotene contents of tomatoes decreased with the storage period, as shown in Figures 46. The performance of the LDPE material in retaining the moisture content of the tomatoes was higher than those of the nanocomposite packaging materials at 10,15 and $27^{\circ} \mathrm{C}$. Also, the film blended with $2 \%$ nanoparticles was able to retain moisture content than the ones blended with 1\% and $0 \%$ nanoparticles (Figure 4). The variance component of moisture content of packaged tomatoes showed that the contribution of packaging materials $(72.5 \%)$ was more than the individual contributions of temperature $(0 \%)$ and storage period $(27.5 \%)$ (Table 4$)$. It is likely that the good barrier to water vapour of the nanocomposite films and the high insulation property of the LDPE might be responsible for the reduction in the moisture loss of the packaged tomatoes. Additionally, the ascorbic acid and $\beta$-carotene contents of tomatoes decreased significantly $(\mathrm{P}<0.05)$ with storage period at 10,15 and $27^{\circ} \mathrm{C}$ (Figures 5 and 6). The abilities of $1 \%$ and $2 \%$ zinc blended nanocomposite films to retaining ascorbic acid and $\beta$-carotene contents of the packaged tomatoes were higher than the one without nanoparticles and the LDPE. The variance components of $\beta$-carotene and ascorbic acid showed that $68.3 \%$ and $65.4 \%$ of the total variability were, respectively, due to storage period than the individual contributions due to temperature and packaging materials (Table 4). The tomatoes in the LDPE film recorded the least ascorbic acid and $\beta$-carotene contents at all temperature and period of packaging probably because of the higher heat of respiration generated in the LDPE. This is in line with the findings of Chaudhry et al. (2008) who reported that essential quality indices of packaged food decrease rapidly with storage period and temperature because of thermal instability.
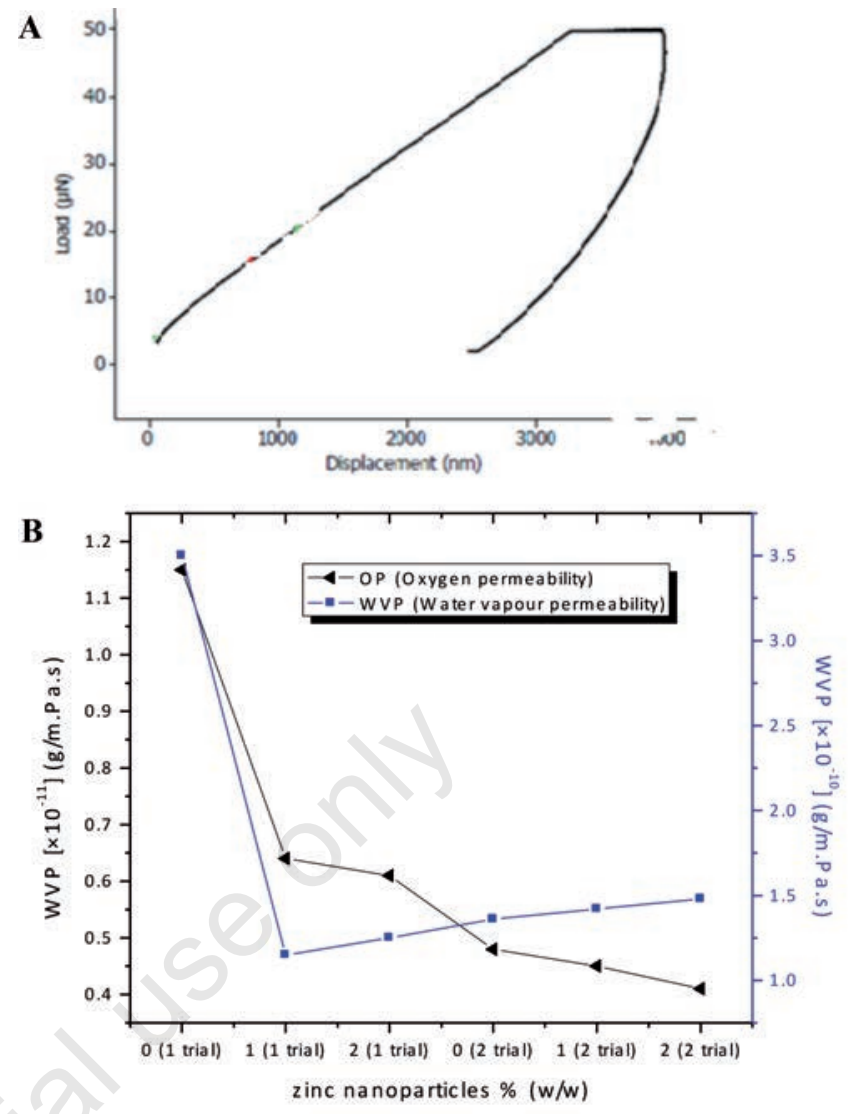

Figure 1. A) Load-displacement profile of cassava starch-zinc nanocomposite film; B) effect of zinc nanoparticles on the permeability of the film.

Table 4. Fully nested analysis of variance of variables.

\begin{tabular}{|c|c|c|c|c|c|c|c|c|}
\hline Parameter & Source & df & SS & MS & $F$ & $\mathbf{P}$ & Var C & $\%$ of total Var C \\
\hline TSS & $\begin{array}{l}\text { Storage period } \\
\text { Temperature } \\
\text { Packaging material } \\
\text { Total }\end{array}$ & $\begin{array}{c}3 \\
8 \\
36 \\
47\end{array}$ & $\begin{array}{c}139.9983 \\
16.6983 \\
353.3100 \\
510.0067\end{array}$ & $\begin{array}{l}46.6661 \\
2.0873 \\
9.8142 \\
-\end{array}$ & $\begin{array}{c}22.357 \\
0.213 \\
- \\
-\end{array}$ & $\begin{array}{c}0.000^{*} \\
0.987 \\
- \\
-\end{array}$ & $\begin{array}{c}3.715 \\
-1.932 \\
9.814 \\
13.529\end{array}$ & $\begin{array}{c}27.46 \\
0.00 \\
72.54 \\
-\end{array}$ \\
\hline TTA & $\begin{array}{l}\text { Storage period } \\
\text { Temperature } \\
\text { Packaging material } \\
\text { Total }\end{array}$ & $\begin{array}{c}3 \\
8 \\
36 \\
47\end{array}$ & $\begin{array}{l}2.1823 \\
0.3476 \\
0.9477 \\
3.4776\end{array}$ & $\begin{array}{c}0.7274 \\
0.0435 \\
0.0263 \\
-\end{array}$ & $\begin{array}{c}16.741 \\
1.651 \\
- \\
-\end{array}$ & $\begin{array}{c}0.001^{*} \\
0.145 \\
- \\
-\end{array}$ & $\begin{array}{l}0.057 \\
0.004 \\
0.026 \\
0.088\end{array}$ & $\begin{array}{c}65.06 \\
4.89 \\
30.05 \\
-\end{array}$ \\
\hline $\mathrm{MC}$ & $\begin{array}{l}\text { Storage period } \\
\text { Temperature } \\
\text { Packaging material } \\
\text { Total }\end{array}$ & $\begin{array}{c}3 \\
8 \\
36 \\
47\end{array}$ & $\begin{array}{c}139.9983 \\
16.6983 \\
353.3100 \\
510.0067\end{array}$ & $\begin{array}{l}46.6661 \\
2.0873 \\
9.8142\end{array}$ & $\begin{array}{c}22.357 \\
0.213 \\
- \\
-\end{array}$ & $\begin{array}{c}0.000^{*} \\
0.987 \\
- \\
-\end{array}$ & $\begin{array}{c}3.715 \\
-1.932 \\
9.814 \\
13.529\end{array}$ & $\begin{array}{c}27.46 \\
0.00 \\
72.54 \\
-\end{array}$ \\
\hline$\beta-C$ & $\begin{array}{l}\text { Storage period } \\
\text { Temperature } \\
\text { Packaging material } \\
\text { Total }\end{array}$ & $\begin{array}{c}3 \\
8 \\
36 \\
47\end{array}$ & $\begin{array}{c}163.7606 \\
38.8200 \\
34.1725 \\
236.7531\end{array}$ & $\begin{array}{c}54.5869 \\
4.8525 \\
0.9492 \\
-\end{array}$ & $\begin{array}{c}11.249 \\
5.112 \\
- \\
-\end{array}$ & $\begin{array}{c}0.003^{*} \\
0.000^{*} \\
- \\
-\end{array}$ & $\begin{array}{l}4.145 \\
0.976 \\
0.949 \\
6.070\end{array}$ & $\begin{array}{c}68.28 \\
16.08 \\
15.64 \\
-\end{array}$ \\
\hline $\mathrm{VC}$ & $\begin{array}{l}\text { Storage period } \\
\text { Temperature } \\
\text { Packaging material } \\
\text { Total }\end{array}$ & $\begin{array}{c}3 \\
8 \\
36 \\
47\end{array}$ & $\begin{array}{c}129.4683 \\
40.0962 \\
20.5326 \\
190.0971\end{array}$ & $\begin{array}{c}43.1561 \\
5.0120 \\
0.5703 \\
-\end{array}$ & $\begin{array}{l}8.611 \\
8.788 \\
- \\
-\end{array}$ & $\begin{array}{c}0.001^{*} \\
0.000^{*} \\
- \\
-\end{array}$ & $\begin{array}{l}3.179 \\
1.110 \\
0.570 \\
4.859\end{array}$ & $\begin{array}{l}65.41 \\
22.85 \\
11.74\end{array}$ \\
\hline TCC & $\begin{array}{l}\text { Storage period } \\
\text { Temperature } \\
\text { Packaging material } \\
\text { Total }\end{array}$ & $\begin{array}{c}3 \\
8 \\
36 \\
47\end{array}$ & $\begin{array}{l}1.958 \times 10^{17} \\
2.078 \times 10^{17} \\
1.526 \times 10^{18} \\
1.930 \times 10^{18}\end{array}$ & $\begin{array}{l}6.526 \times 10^{16} \\
2.597 \times 10^{16} \\
4.240 \times 10^{16} \\
-\end{array}$ & $\begin{array}{c}2.513 \\
0.613 \\
- \\
-\end{array}$ & $\begin{array}{c}0.132 \\
0.761 \\
- \\
-\end{array}$ & $\begin{array}{c}3.274 \times 10^{15} \\
-4.108 \times 10^{15} \\
4.240 \times 10^{16} \\
4.568 \times 10^{16}\end{array}$ & $\begin{array}{c}7.17 \\
0.00 \\
92.83 \\
-\end{array}$ \\
\hline
\end{tabular}

df, degree of freedom; SS, sum of square; MS, mean square; Var C, variable component; \% of Total Var C, \% of total variance component; TSS, total soluble solids; TTA, titratable acidity; MC, moisture content; $\beta$-C, $\beta$ carotene; VC, ascorbic acid; TCC, total coliform count. *Significant at $\mathrm{P}<0.05$. 

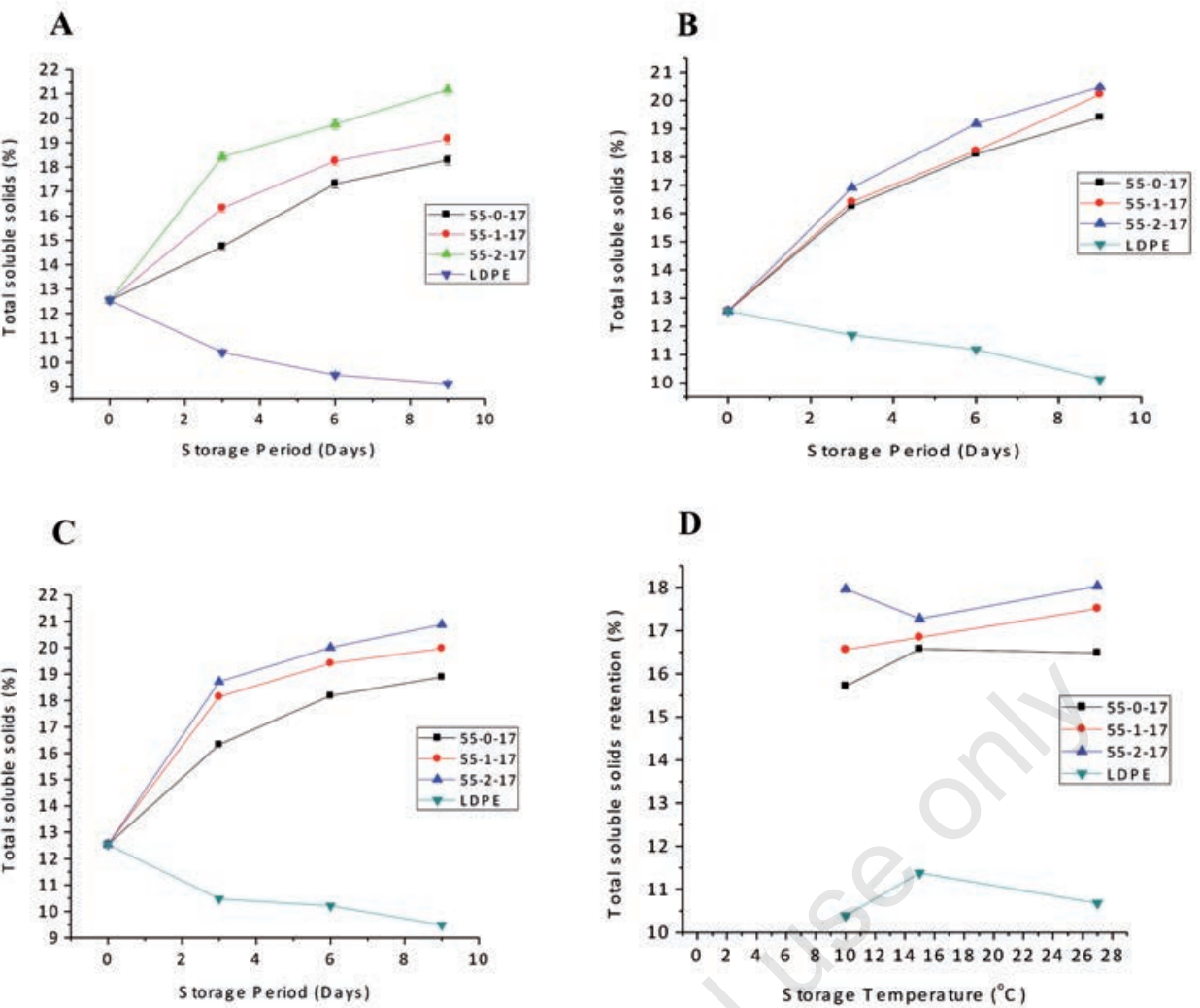

D

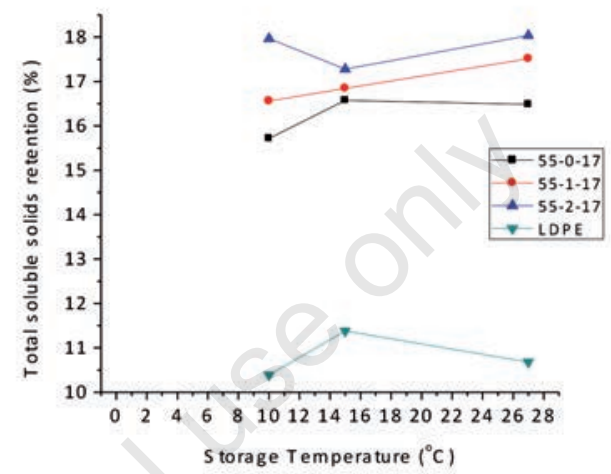

Figure 2. Effect of storage period and packaging materials on total soluble solids of tomatoes at/and (A) $10^{\circ} \mathrm{C}$ (B) $15^{\circ} \mathrm{C}$ (C) $27^{\circ} \mathrm{C}$ (D) degree of total soluble solids retention.
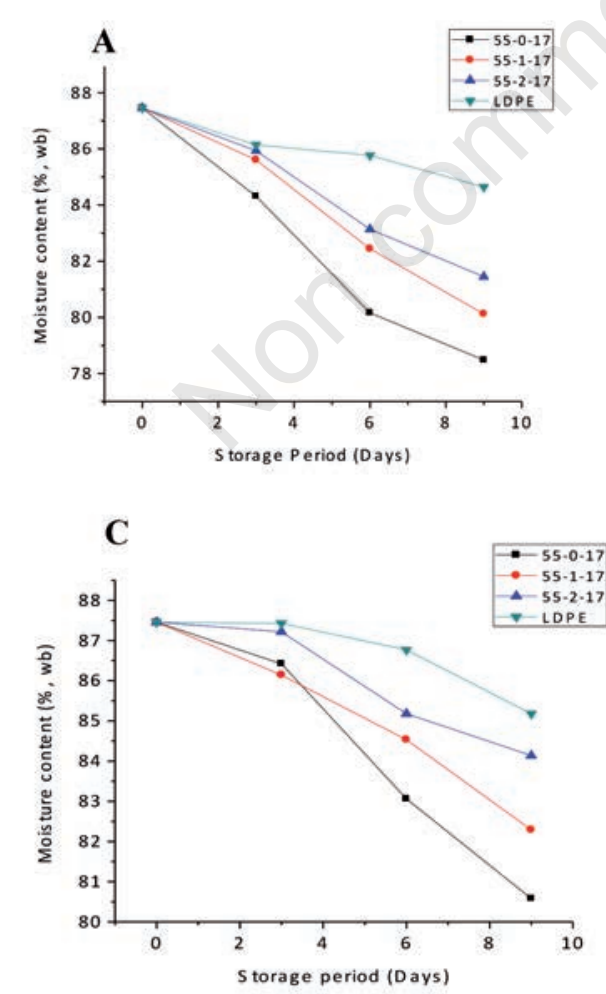
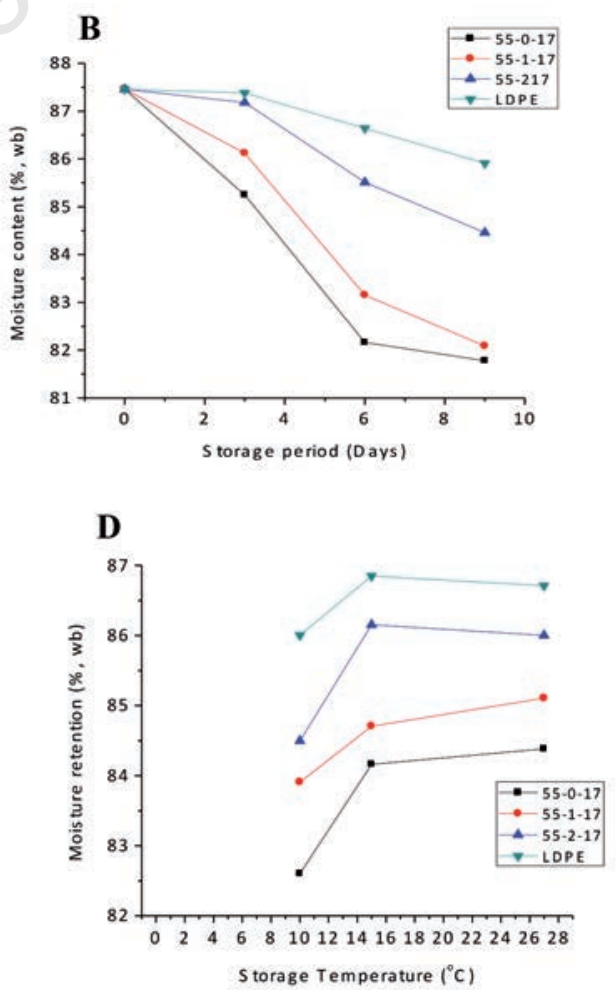

Figure 3. Effect of storage period and packaging materials on moisture content of tomatoes at/and (A) $10^{\circ} \mathrm{C}(\mathrm{B}) 15^{\circ} \mathrm{C}(\mathrm{C}) 27^{\circ} \mathrm{C}(\mathrm{D})$ degree of moisture retention. 

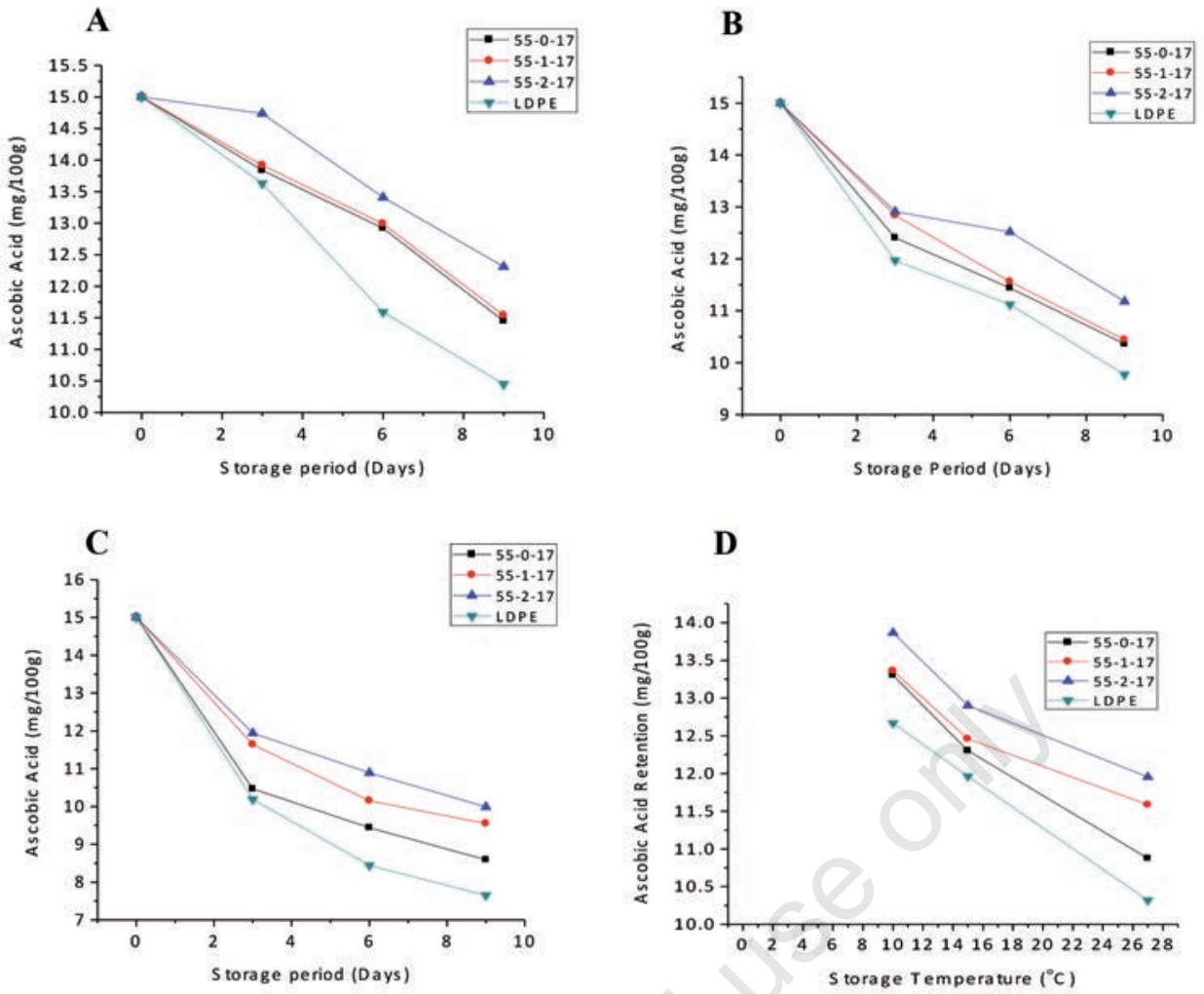

D

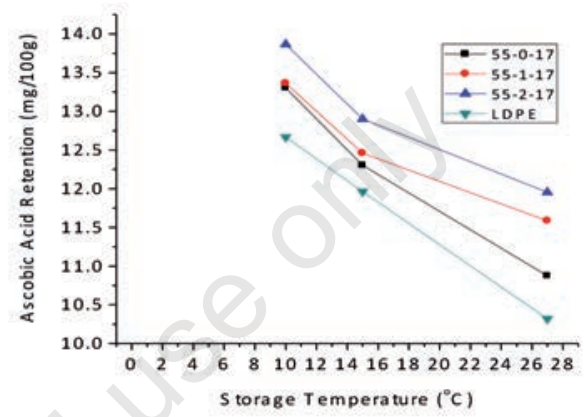

Figure 4. Effect of storage period and packaging materials on ascorbic acid content of tomatoes at/and (A) $10^{\circ} \mathrm{C}(\mathrm{B}) 15^{\circ} \mathrm{C}(\mathrm{C}) 27^{\circ} \mathrm{C}$ (D) degree of ascorbic acid retention.

A

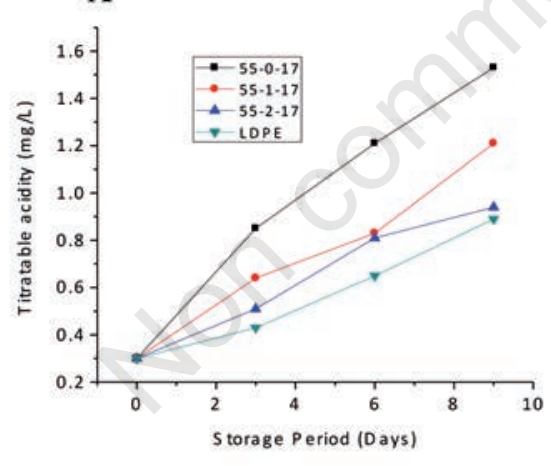

C

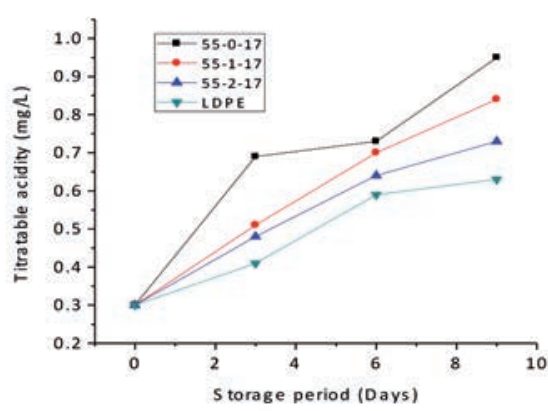

\section{B}

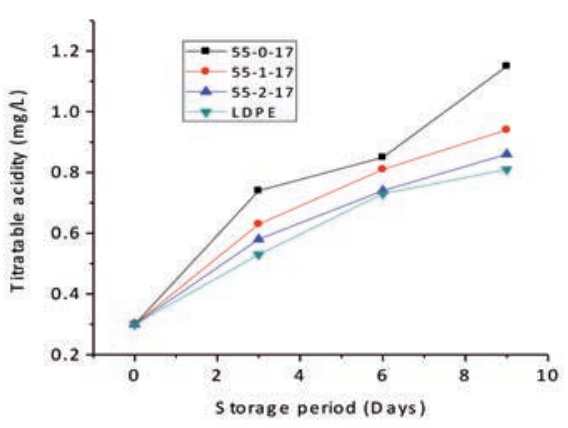

D

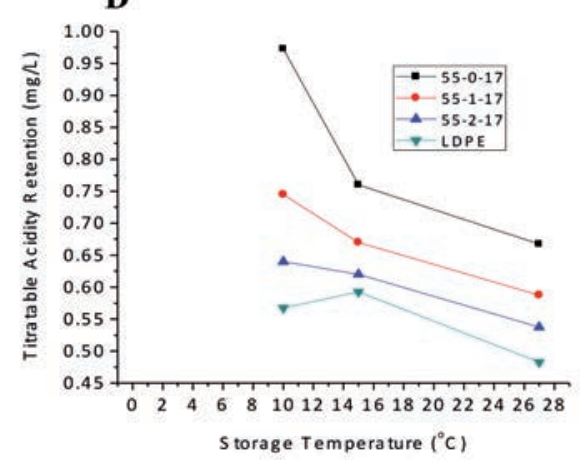

Figure 5. Effect of storage period and packaging materials on titratable acidity of tomatoes at/and (A) $10^{\circ} \mathrm{C}(\mathrm{B}) 15^{\circ} \mathrm{C}(\mathrm{C}) 27^{\circ} \mathrm{C}(\mathrm{D})$ degree of titratable acidity retention. 
A

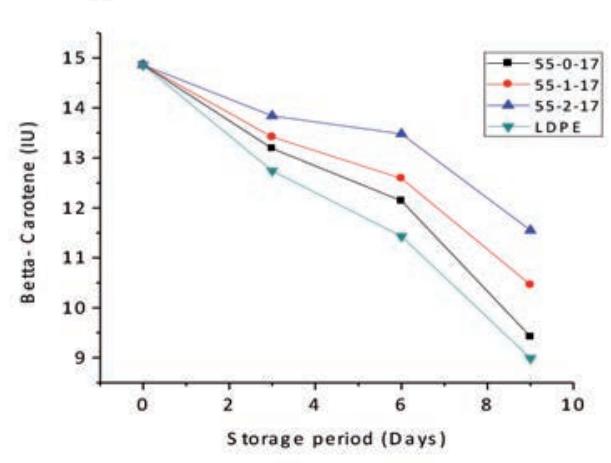

C

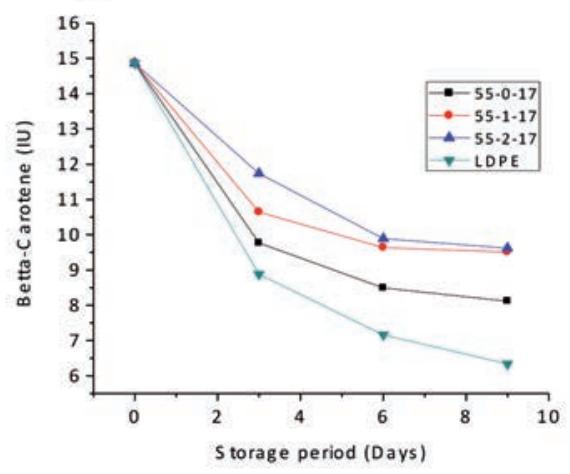

B

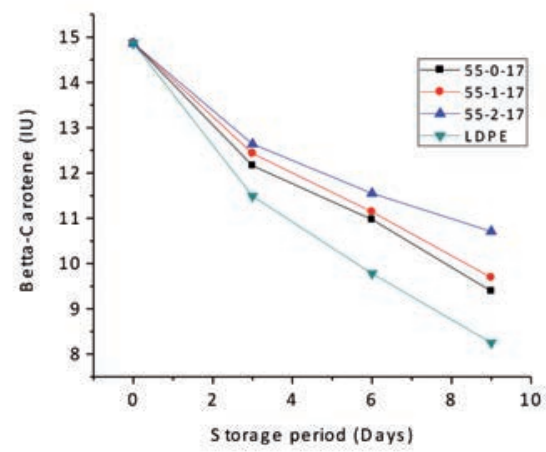

D

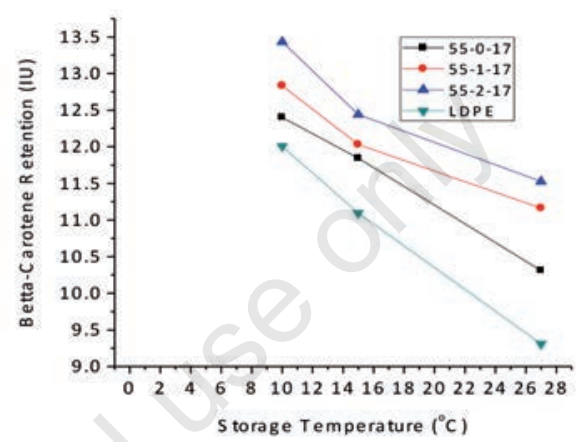

Figure 6. Effect of storage period and packaging materials on $\beta$-carotene content of tomatoes at/and $(\mathrm{A}) 10^{\circ} \mathrm{C}(\mathrm{B}) 15^{\circ} \mathrm{C}(\mathrm{C}) 27^{\circ} \mathrm{C}(\mathrm{D})$ degree of $\beta$-carotene retention.

A

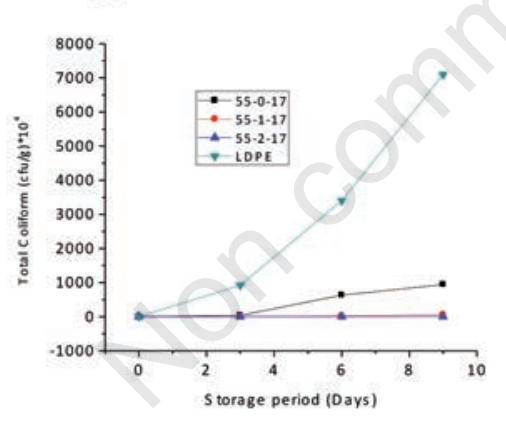

C

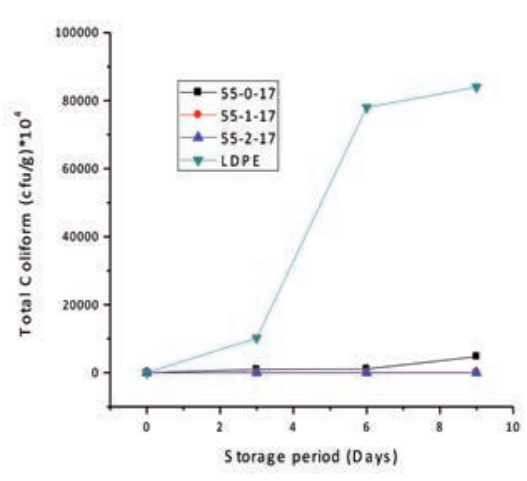

B

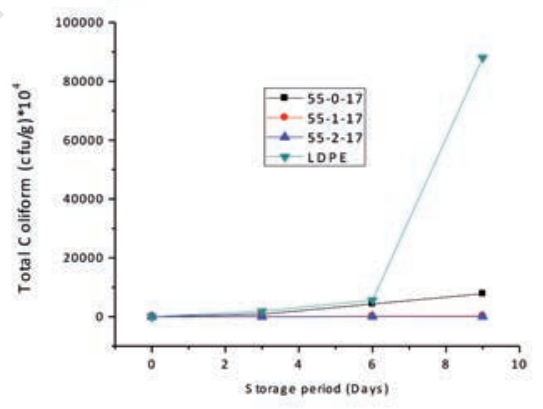

D

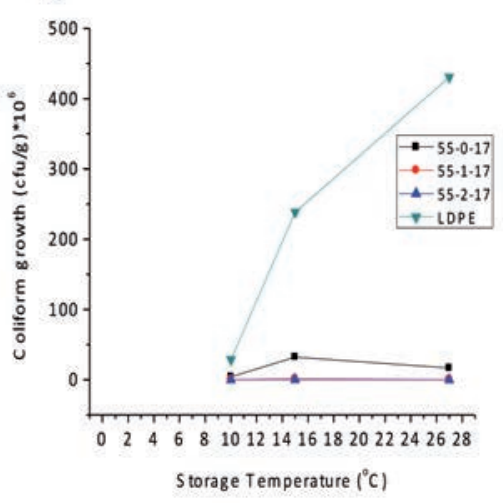

Figure 7. Coliform growth curves of packaged tomatoes at/and (A) $10^{\circ} \mathrm{C}$ (B) $15^{\circ} \mathrm{C}$ (C) $27^{\circ} \mathrm{C}$ (D) degree of coliform growth. 


\section{Effects of temperature and period on the microbial growth of packaged tomatoes}

The effects of the period and packaging materials on the amount of total coliform found on the surface of the packaged tomatoes at 10,15 and $27^{\circ} \mathrm{C}$ are shown in Figures $7 \mathrm{~A}-\mathrm{C}$, respectively. It can be seen that the microbial load on the surface of the packaged tomatoes increased with the storage period irrespective of the kind of material used for packaging. However, the increase in the microbial load was not significant at $\mathrm{P}<0.05$, as can be seen in the ANOVA shown in Table 4. The LDPE material, which recorded the highest amount of the total coliform, performed poorly in comparison with the other kinds of the packaging materials used. The amount of the total coliform recorded in the film with no nanoparticles is comparable to the LDPE materials, but is far less than the coliform counts in the films containing the fillers, as shown in Figure 7D. It is likely that the absence of the nanoparticles might be responsible for the high amount of the coliform growth in the tomatoes packaged in the film with $0 \%$ zinc nanoparticles. The films containing the nanoparticles recorded significantly lower amount of total coliform, which decreased further with storage period and temperature. This agrees with the findings of Joseph and Morrison (2006) who was of the opinion that the growth rate of the microorganisms decreased with storage period and temperature in the nanocomposite packaging of fresh fruits and vegetables for shelf-life extension. In a related research, Lopez et al. (2015) reported that the performance of the biodegradable film, developed from cornstarch reinforced with talc nanoparticles, for vegetable packaging increased with increase in the concentration of the fillers. Consequently, the presence of zinc nanoparticles in the crystalline structure of the film can create a large interface in the resulting matrix between the fillers, starch and glycerol. This in turn is capable of altering the growth rate of the microorganisms by scavenging way the excess oxygen, which is capable of encouraging microbial growth and causing tomatoes deterioration, within the packaged atmosphere.

\section{Conclusions}

Nanotechnology will likely impact virtually every aspect of the food sector in some way. It is an acceptable fact that nanocomposite films have the ability to inhibit the growth of deteriorating microorganisms on the surface of packaged fruits and vegetables. This research was conducted to evaluate the performance of cassava starch-zinc nanocomposite films for tomatoes packaging at temperature and period ranges of $10-27^{\circ} \mathrm{C}$ and $0-9$ days, respectively. The $W V P$ of the films increased significantly $(\mathrm{P}<0.05)$ with concentrations of the zinc nanoparticles $(0-2 \%)$, whereas the $O P$ decreased significantly $(\mathrm{P}<0.05)$ with the nanoparticles. The lower $O P$ of the nanocomposite film may mean that any oxidative process occurring in the packaged tomatoes can be curtailed thereby slowing the rate of deterioration. The hardness, creep, elastic and plastic works decreased generally with the nanoparticles. The results also showed significant $(\mathrm{P}<0.05)$ evidence for storage period and temperature affecting the overall performance of the nanocomposite films for use in packaging tomatoes.

\section{References}

Amidi-Fazli F., Amidi-Fazli N. 2015. Barrier properties of starch- ethylene vinyl alcohol nanocomposites. Int. J. Chem. Mol. Nucl. Mat. Metal. Eng. 9:249-52.

Auras R., Singh S.P., Singh J.J. 2005. Evaluation of oriented (polylactide) polymers vs. existing PET and oriented PS for fresh food service containers. Pack. Tech. Sci. 18:207-16.

Avella M., de Vlieger J.J., Errico M.E., Fischer S., Vacca P., Volpe M.G. 2005. Biodegradable starch/clay nanocomposite films for food packaging applications. F. Chem. 93:467-74.

Aydinli M., Tutas M. 2000. Water sorption and water vapour permeability of polysaccharide (locust bean gum) based edible films. Lebensm-Wiss Univ. Technol. 33:63-7.

Castelló R., Ferreira A.R., Costa N., Fonseca I.M., Alves V.D., Coelhoso I.M. 2010. Nanocomposite films obtained from carrageenan/pectin biodegradable polymers. Int. Conf. F. Inno. 41:1-4.

Chaudhry Q.S., Blackburn M., Ross J., Boxall B.A., Castle L. 2008. Applications and implications of nanotechnologies for the food sector. Food Add. Cont. 25:241-58.

Chinma C.E., Ariahu C.C., Alakali J.S. 2015. Effect of temperature and relative humidity on the water vapour permeability and mechanical properties of cassava starch and soy protein concentrate based edible films. J. Food Sci. Technol. 52:2380-6.

Dai L., Qui C., Xiong L., Sun Q. 2015. Characterisation of corn starch-based films reinforced with taro starch nanoparticles. Food Chem. 174:82-8.

de Moraes J.O., Muller C.M., Laurindo J.B. 2012. Influence of the simultaneous addition of bentonite and cellulose fibers on the mechanical and barrier properties of starch composite-films. Food Sci. Technol. Int. 18:35-45.

EFSA (European Food Safety Authority), 2016. Panel on food contact materials, enzymes, flavourings and processing aids. Ministry of Sports, Welfare and Sport, the Netherlands.

Emamifar A., Kadivar M., Shahedi M., Solaimanianzad S. 2011. Effect of nanocomposite packaging containing $\mathrm{Ag}$ and $\mathrm{ZnO}$ on inactivation of Lactobacillus plantarum in orange Juice. Food Cont. 22:408-13.

Fadeyibi A., Osunde Z.D., Agidi G., Evans E.C. 2014. Flow and strength properties of cassava and yam starch-glycerol composites essential in the design of handling equipment for granular solids. J. Food Eng. 129:38-46.

Fadeyibi A., Osunde Z.D., Agidi G., Evans E.C. 2016a. Green polymer composites technology: properties and applications. In: S. Inamuddin (Ed.), Mixing index of a starch composite extruder for food packaging application. CRC Press and Taylor \& Francis Group, Asia Pacific, pp 335-346.

Fadeyibi A., Osunde Z.D., Agidi G., Idah P.A., Egwim E.C. 2016b. Development and optimisation of cassava starch-zincnanocomposite film for potential application in food packaging. J. Food Process Technol. 7:591.

Guilbert S., Gontard N., Gorris G.M. 1996. Prolongation of the shelf life of perishable food products using biodegradable films and coatings. Lebensm-Wiss Univ. Techn. 29:10-17.

Henriette M.C., Azeredo I.H.C., Mattoso D.T., Williams G., Roberto J.A., Tara H.M. 2009. Nanocomposite edible films from mango puree reinforced with cellulose nanofibers. J. Food Sci. 74:201-8.

Hernandez-Izquierdo V.M., Krochta J.M. 2008. Thermoplastic processing of proteins for film formation - a review. J. Food Sci. 73:30-9.

Janhasgir S., Leber M. J. 2007. Biodegradable food packaging: an environmental imperative. Available from: https://www. nerac.com/biodegradable-food-packaging-an-environmentalimperative/ Accessed: 15 May, 2014. 
Jian S., Chen G., Hsu W. 2013. Mechanical properties of $\mathrm{Cu} O$ thin films by nanoindentation. Mat. 6:4505-13.

Jin T., Sun D., Su J. Y., Zhang H., Sue H. J. 2009. Antimicrobial efficacy of zinc oxide quantum dots against Listeria monocytogenes, Salmonella enteritidis, and Escherichia coli. J. Food Sci. 74:46-52.

Jorge M.F.G., Vanin F.M., de Carvalho R.A., Moraes I.C.F., Bittante A.M.Q.B., Nassar S.F., Sobral P.J.A. 2014. Mechanical properties of gelatin nanocomposite films prepared by spreading: effect of montmorillonite concentration. Available from: http://www.icef11.org/content/papers/fms/fms 188.pdf

Joseph T., Morrison M. 2006. Nanotechnology in Agriculture and Food. A Nanoforum Report, Institute of Nanotechnology, pp. 34-45. Available from: http://cordis.europa.eu/pub/nanotechnology/docs/nanotechnology in agriculture and food.pdf

Kampeerapappun P., Srikulkit K., Pentrakoon D. 2004. Preparation of cassava starch/montmorillonite nanocomposite film. J. Sci. Res. Chulalongkorn Univ. 29 (2):183-197.

Lopez O.V., Castillo L.A., Garcia M.A., Villar M.A., Barbosa S.E. 2015. Food packaging bags based on thermoplastic cornstarch reinforced with talc nanoparticles. Food Hydrocol. 43:18-24.

Luo Z, Cheng W., Chen H., Fu X, Peng X, Luo F, Nie L. 2013. Preparation and properties of enzyme-modified cassava starchzinc complexes. J. Agric. Food Chem. 61:4631-8.

Nafchi A.M., Nassiri R., Sheibani S., Ariffin F, Karim AA. 2013. Preparation and characterisation of bionanocomposite films filled with nanorod-rich zinc oxide. Carbohydr. Polym. 96:233-9.
Nascimento T.A., Calado V., Carvalho C.W.P. 2012. Development and characterisation of flexible film based on starch and passion fruit mesocarp flour with nanoparticles. Food Res. Int. 49:588-95.

Onwuka G.I. 2005. Food analysis and instrumentation theory and practice. University of Agriculture, Umudike, Nigeria Press, pp 162-204.

Ortega-Rivas E. 2003. Review and research trend in food powder processing. World Congress on Particle Technology, Sydney, Australia, pp. 18-25.

Syed V.A., Nagamani H., Yeshwanth A., Sundaram S. 2013. Nanoindentation behaviour of ultrathin polymeric films. Ad. Aero. Sci. Appl. 3:235-8.

Tall P.D., Ndiaye S., Beye A.C., Zong Z., Soboyejo W.O., Lee H.J., Ramirez A.G., Rajan K. 2007. Nanoindentation of Ni-Ti thin films. Mat. Man. Proc. 22:175-9.

Tankhiwale R., Bajpai S.K. 2012. Preparation, characterisation and antibacterial applications of $\mathrm{ZnO}$-nanoparticles coated polyethylene films for food packaging. Colloids Surf. B Biointerfaces. 90:16-20.

Teodoro A.P., Mali S., Romero N., de Carvalho GM. 2015. Cassava starch films containing acetylated starch nanoparticles as reinforcement: physical and mechanical characterisation. Carbohydr Polym. 126:9-16.

Zhang L, Ding Y, Povey M, York D. 2008. ZnO nanofluids - a potential antibacteria agent. Prog. Nat. Sci. 18:939-44. 